Guaju - Revista Brasileira de Desenvolvimento Territorial Sustentável

Programa de Pós-Graduação em Desenvolvimento Territorial Sustentável (PPGDTS/UFPR)

Publicação semestral. v. 3, n. 2, jul./dez. 2017

\title{
Expediente
}

\section{Equipe editorial:}

Marisete T. Hoffmann-Horochovski

Rodrigo Rossi Horochovski

Aline de Oliveira Gonçalves

Simone Ferreira Naves Angelin

Etienne Cesar Rosa Vaccarelli

\section{Fotografia da capa:}

Puxar a canoa pra cima - Expressão utilizada pelos pescadores artesanais para o ato da retirada da canoa do mar com o auxílio de uma carretinha

Autor da fotografia:

Diomar Augusto de Quadros

\section{Diagramação da capa:}

William Leal 